Review Article

\title{
Risk Factors of Multidrug-Resistant Bacteria in Lower Respiratory Tract Infections: A Systematic Review and Meta-Analysis
}

\author{
Gang Chen, ${ }^{1}$ Kailiang Xu, ${ }^{1}$ Fangyuan Sun, ${ }^{1}$ Yuxia Sun, ${ }^{1}$ Ziyuan Kong, \\ and Bangjiang Fang $\mathbb{D}^{2}$ \\ ${ }^{1}$ Department of Intensive Care Medicine, Seventh People's Hospital of Shanghai University of Traditional Chinese Medicine, \\ Shanghai 200137, China \\ ${ }^{2}$ Department of Emergency, LongHua Hospital of Shanghai University of Traditional Chinese Medicine, Shanghai 200032, China
}

Correspondence should be addressed to Bangjiang Fang; fangbji@163.com

Received 25 March 2020; Revised 13 May 2020; Accepted 26 May 2020; Published 30 June 2020

Academic Editor: Lucia Lopalco

Copyright (c) 2020 Gang Chen et al. This is an open access article distributed under the Creative Commons Attribution License, which permits unrestricted use, distribution, and reproduction in any medium, provided the original work is properly cited.

Background. Multidrug-resistant (MDR) bacteria are the main cause of lower respiratory tract infections (LRTIs) with high mortality. The purpose of this study is to identify the risk factors associated with MDR by performing a systematic review and meta-analysis. Methods. PubMed, EMBASE (via Ovid), and Cochrane Library were systematically searched for studies on the risk factors for MDR bacteria in LRTIs as of November 30, 2019. Literature screening, data abstraction, and quality assessment of the eligible studies were performed independently by two researchers. Results. A total of 3,607 articles were retrieved, of which 21 articles representing 20 cohort studies published in English were included after title/abstract and full-text screening. Among the 21 articles involving 7,650 patients and 1,360 MDR organisms, ten reported the risk factors for MDR Gram-positive bacteria (GPB) and Gram-negative bacteria (GNB), ten for MDR GNB, and one for MDR GPB. The meta-analysis results suggested that prior antibiotic treatment, inappropriate antibiotic therapy, chronic lung disease, chronic liver disease and cerebral disease, prior MDR and PA infection/colonization, recent hospitalization, longer hospitalization stay, endotracheal tracheostomy and mechanical ventilation, tube feeding, nursing home residence, and higher disease severity score were independent risk factors for MDR bacteria. Conclusions. This review identified fourteen clinical factors that might increase the risk of MDR bacteria in patients with LRTIs. Clinicians could take into account these factors when selecting antibiotics for patients and determine whether coverage for MDR bacteria is required. More well-designed studies are needed to confirm the various risk factors for MDR bacteria in the future.

\section{Introduction}

LRTIs are a leading cause of morbidity and mortality around the world. According to the Global Burden of Diseases, Injuries, and Risk Factors (GBD) Study 2017, nearly 2.56 million deaths resulted from LRTIs in 2017, making LRTI the fifth leading cause of mortality for all ages [1]. Besides, more than $50 \%$ of LRTI deaths in 2016 were attributable to bacterial aetiologies [2]. Antibiotics are commonly prescribed for antibiotic therapy [3], and antimicrobial resistance is becoming more widely recognized as a leading global health threat [2]. The prevalence of MDR pathogens particularly with carbapenem-resistant Klebsiella pneumoniae (CRKP) has sharply increased in recent years, posing significant challenges on anti-infection, and the mortality of patients with MDR bacterial infections was significantly higher than that of patients with non-MDR bacterial infections [4-7]. World Health Organization surveillance reports indicate that the number of patients with LRTIs caused by antibiotic-resistant bacteria continues to increase and such a disease is widespread [8].

Previous studies have found that many risk factors might be associated with the development of MDR bacteria, including prior antibiotic use [9-15], recent hospitalization $[15,16]$, nursing home residence $[10,11,15]$, previous colonization/infection with MDR pathogens $[16,17]$, ICU stay $>7$ days [9], APACHE II score [18], chronic pulmonary disease $[17,18]$, cardiac disease $[16,18]$, and tracheostomy/ 
mechanical ventilation [19]. The Clinical Practice Guidelines by the Infectious Diseases Society of America and the American Thoracic Society 2016 (IDSA/ATS guidelines 2016) listed the risk factors for MDR pathogens in hospitalacquired pneumonia (HAP) and ventilator-associated pneumonia (VAP) [20]. Due to the emergence of new studies in recent years [14, 17], no review has systematically summarized the risk factors for MDR bacterial infection in patients with LRTIs, so we conducted this systematic review and meta-analysis to identify the risk factors associated with MDR bacteria in patients with LRTIs and to provide evidence for clinical practice.

\section{Materials and Methods}

We conducted the study following the Preferred Reporting Items for Systematic Review and Meta-Analyses (PRISMA) guidelines [21]. There was no requirement for ethical approval because we analyzed scientific literature already in the public domain.

2.1. Search Strategy. PubMed, EMBASE (via Ovid), and Cochrane Library were searched systematically for studies on the risk factors for MDR bacteria in LRTIs up to November 30, 2019. The free text words such as "Gram-Negative Bacteria," "Acinetobacter baumannii," "Pseudomonas aeruginosa," "Escherichia coli," "Klebsiella pneumoniae," "Methicillin-Resistant Staphylococcus aureus," "MRSA," "Enterobacteriaceae," "Carbapenem-Resistant Enterobacteriaceae," "Multiple Drug Resistance," "Respiratory Tract Infections," "Pneumonia," "Hospital-acquired pneumonia," "Ventilator-associated pneumonia," "Communityacquired pneumonia (CAP)," and "Bronchopneumonia" and Medical Subject Headings (MeSH) were combined with the Boolean operators "AND" or "OR." We listed the detailed retrieval strategies in Tables S1-S3 in the Supplementary Materials. Additionally, we checked through the reference lists of relevant studies to see if these references include reports of other studies that might be eligible for the review.

2.2. Study Selection. We had access to all published articles that evaluated the risk factors for MDR bacteria in LRTIs and included prospective or retrospective cohorts that included adult patients with LRTIs and were published in English. We excluded studies if they were case reports, case series, animal studies, or review; if they included nonrespiratory tract infection patients or pediatric patients; if they reported MDR organisms less than ten cases; if they merely reported the results of unadjusted analysis; and if the full texts of them were unavailable. For articles that covered the same population as other articles, if the articles provided new information, we considered them were qualified, and if not, we chose the article with better homogeneity when it was synthesized with other studies.

The literature selection was performed independently by two researchers (G. C and KL. X), and any disagreements were resolved by consensus. We accepted MDR organisms as defined by individual studies, even if the definitions were inconsistent across studies. One definition of MDR is the development of resistance to more than three antibiotic classes known to be active against these pathogens [22] (Definition A), and the other considered methicillin-resistant Staphylococcus aureus (MRSA), extended-spectrum beta-lactamases (ESBLs), CRKP and Escherichia coli (Eco), Pseudomonas aeruginosa (PA), Acinetobacter baumannii (AB), and Stenotrophomonas maltophilia (SMA) as MDR pathogens according to the IDSA/ATS Guidelines 2005 [23] (Definition B). Besides, some studies did not elaborate on the definition of MDR bacteria (No definition). In the review, the hospital setting comprised all types of units, including intensive care units, emergency room/casualty, or other wards.

2.3. Data Abstraction. Two researchers (G.C and KL.X) independently extracted the following information: author, year of publication, countries, type of study, setting, sample sizes, the definition of MDR, age, and all reported risk factors. If no consensus can be reached on the disagreement, another reviewer would participate in the decision-making. We used standardized data extraction sheets made by Microsoft Excel 2019 for data extraction.

2.4. Risk of Bias Assessment of Eligible Studies. We conducted the risk of bias assessment of eligible studies based on Quality in Prognosis Studies (QUIPS) tool [24]. The risk of bias assessment covered the following six domains: study participation, study attrition, prognostic factor measurement, outcome measurement, study confounding, and statistical analysis and reporting. Considering all relevant issues, each of these six domains can be rated as the one with high, medium, or low potential deviation risk. For the overall rating, we followed the approach from Foroutan et al. [25] and classified studies with five or six low-risk domains as at overall low risk of bias, studies with two or more high-risk domains as at overall high risk of bias, and remaining studies as at overall moderate risk of bias.

2.5. Statistical Analysis. We calculated the pooled odds ratio (OR) with a $95 \%$ confidence interval (CI). The $Q$ statistic (significant when $P<0.10$ ) was employed to explore the heterogeneity across studies, and then the $I^{2}$ statistic was used to quantify the extent of heterogeneity. We considered that $I^{2}>50 \%$ represented substantial inconsistency or significant statistical heterogeneity, and data synthesis was performed in the DerSimonian and Laird (DL) randomeffects model. Subsequently, subgroup analyses were conducted according to diagnosis (pneumonia, CAP, HAP, VAP, and other LRTIs), kinds of organisms (CPB, GNB, and $\mathrm{CPB}$ and GNB), and definitions of MDR (Definition A, Definition $B$, and No definition) to explore the sources of heterogeneity. Moreover, fixed-effects model and Hartung-Knapp-Sidik-Jonkman (HKSJ) random-effects model were used to perform sensitivity analysis in order to verify the robustness of the meta-analysis results. The potential 
publication bias of eligible studies was identified using Begg's test and Egger's test for risk factors reported in nine or more studies. We considered a $P$ value of less than 0.05 to be statistically significant. The trim and fill method was applied to adjust the results of the pooled analysis in the case of publication bias. All statistical tests were two-sided. Statistical software Stata version 14.0 (StataCorp, College Station, TX, 2014) and R version 4.0.0 were employed in the review.

\section{Results}

A total of 3, 607 articles were retrieved, and 21 articles [14-17, 19, 26-41] representing 20 cohort studies published in English between 2006 and 2019 were included after title/ abstract and full-text screening. The PRISMA 2009 flow diagram in literature screening can be referred to Figure 1. Studies excluded in the full-text screening process are listed in Table S2 in the Supplementary Materials.

Among the 21 eligible articles, nine were prospective studies $[14,16,17,19,32,37,39-41]$ and twelve were retrospective studies [26-31, 33-36, 38]. Three articles $[16,17,31]$ were conducted at multiple centers. Except for an international multicenter study [16, 17], all other studies $[14,15,19,26-41]$ were confined to one country. The majority of the populations included were patients with pneumonia [14-17, 26-29, 31-41]. The mean age of the study subjects ranged from 42.6 years to 74.9 years, and the males accounted for $44.5 \%$ to $89.7 \%$ of all the study subjects. We summarized the baseline characteristics of the included studies in Table 1. The 21 eligible articles involved 7,650 patients and 1,360 MDR organisms, of which ten reported the risk factors for MDR GPB and GNB $[15,19,26,28,31,33,34,38,39,41]$, ten for MDR GNB $[14,16,17,27,29,30,32,35,36,40]$, and one for MDR GPB [37].

The risk of bias of the included articles is listed in Table 2. The overall risk of bias of 15 articles $[14-17,19,27,29-31,33,35,36,38,39,41]$ is rated as low, four $[26,34,37,40]$ as moderate, and two [28, 32] as high, indicating that most of the included studies had intermediate or higher quality.

3.1. Meta-Analysis Results. In the meta-analysis, the risk factors significantly associated with the acquisition of MDR bacteria are described in the Results section. Additionally, other risk factors that are statistically significantly associated with the acquisition of MDR bacteria but are not suitable for meta-analysis are listed in Table S3 in the Supplementary Materials.

3.2. Antibiotic Treatment. Prior antibiotic treatment is the most frequently reported risk factor that is correlated with the acquisition of MDR bacteria [14-16, 19, 26, 28, 30, 34, 36-38, 41]. Six of the included studies $[14,19,30,36,38,41]$ defined prior antibiotic treatment as the antibiotic use within 30 days before admission, while another two studies $[15,26]$ as 90 days before diagnosis and one study [16] as 12 months before diagnosis. The remaining three studies $[28,34,37]$ did not specify the period between the diagnosis and the last antibiotic treatment. In the meta-analysis, twelve studies [14-16, 19, 26, 28, 30, 34, 36-38, 41] indicated that prior antibiotic treatment had a statistically significant association with the acquisition of MDR bacteria (OR: 2.35; $95 \%$ CI: 1.92 to $3.18 ; I^{2}=20.8 \%$ ) in the random-effects model (Figure 2). Besides, two studies [27, 29] demonstrated that inappropriate antibiotic therapy was also associated with an increased risk of acquisition (OR: 14.99 ; $95 \%$ CI: 8.56 to 26.26.12; $\left.I^{2}=41.1 \%\right)$ using the random-effects model.

3.3. Comorbidities. In patients, chronic lung disease $[16,17,26,36,38]$ including chronic obstructive pulmonary disease $[17,26,38]$ and chronic liver disease $[16,32]$, cerebral disease $[33,36,40]$ including encephalopathy grades II-IV [40], and cerebrovascular events $[33,36]$ could increase the risk of the development of MDR bacteria, while cardiac disease $[33,36,40]$ and kidney disease requiring renal replacement therapy $[15,38,41]$ did not add the risk of MDR bacterial infection. The results of the meta-analysis are listed in Table 3.

3.4. Prior Infection/Colonization. Three studies [15, 16, 33] demonstrated that patients with prior MDR infection/colonization in the previous 12 months (OR: 3.80; 95\% CI: 1.53 to $9.41 ; I^{2}=60.8 \%$ ) had a significantly increased risk of being infected with MDR bacteria in the random-effects model, so did the patients with prior PA infection/colonization (OR: 10.29; $95 \%$ CI: 5.03 to $21.07 ; I^{2}=0.0 \%$ ) reported in two studies $[15,17]$.

3.5. Hospitalization. For recent hospitalization, two of the included studies $[15,31]$ defined it as hospitalization within the last 3 months, while one study [16] as 12 months and one study [26] did not specify the meaning of "recent".

In the random-effects model, recent hospitalization [15, 16, 26, 31] (OR: 2.47; 95\% CI: 1.47 to $4.15: I^{2}=10.6 \%$, four studies) or healthcare exposure prior to admission [15, 33, 34] (OR: 3.10 ; 95\% CI: 1.94 to $4.97 ; I^{2}=0.0 \%$, three studies) was identified with increased odds of MDR bacterial infection. Moreover, the longer the hospitalization stay, the greater the risk of infection with MDR bacteria (OR: 1.03; $95 \%$ CI: 1.01 to $1.06 ; I^{2}=76.3 \%$, four studies) $[15,34,35,41]$.

3.6. Hospital Interventions. Previous or present endotracheal intubation increased the risk of MDR bacteria obviously (OR: 6.56 ; 95\% CI: 1.03 to $41.94 ; I^{2}=91.3 \%$, three studies) $[19,26,40]$, which was also applicable to patients treated with mechanical ventilation (OR: 7.97; 95\% CI: 2.41 to 26.33 ; $I^{2}=65.1 \%$, three studies) $[17,33,36]$. In patients requiring enteral nutritional support, tube feeding (OR: 2.95; 95\% CI: 1.12 to $7.80 ; I^{2}=0.0 \%$, two studies) $[16,31]$ was also a factor that increased the risk of MDR bacteria.

3.7. Others. Furthermore, the higher the disease severity scores, the higher the risk of the infection with MDR bacteria (OR: $2.29 ; 95 \% \mathrm{CI}: 1.41$ to $3.74 ; I^{2}=11.2 \%$, two studies) 


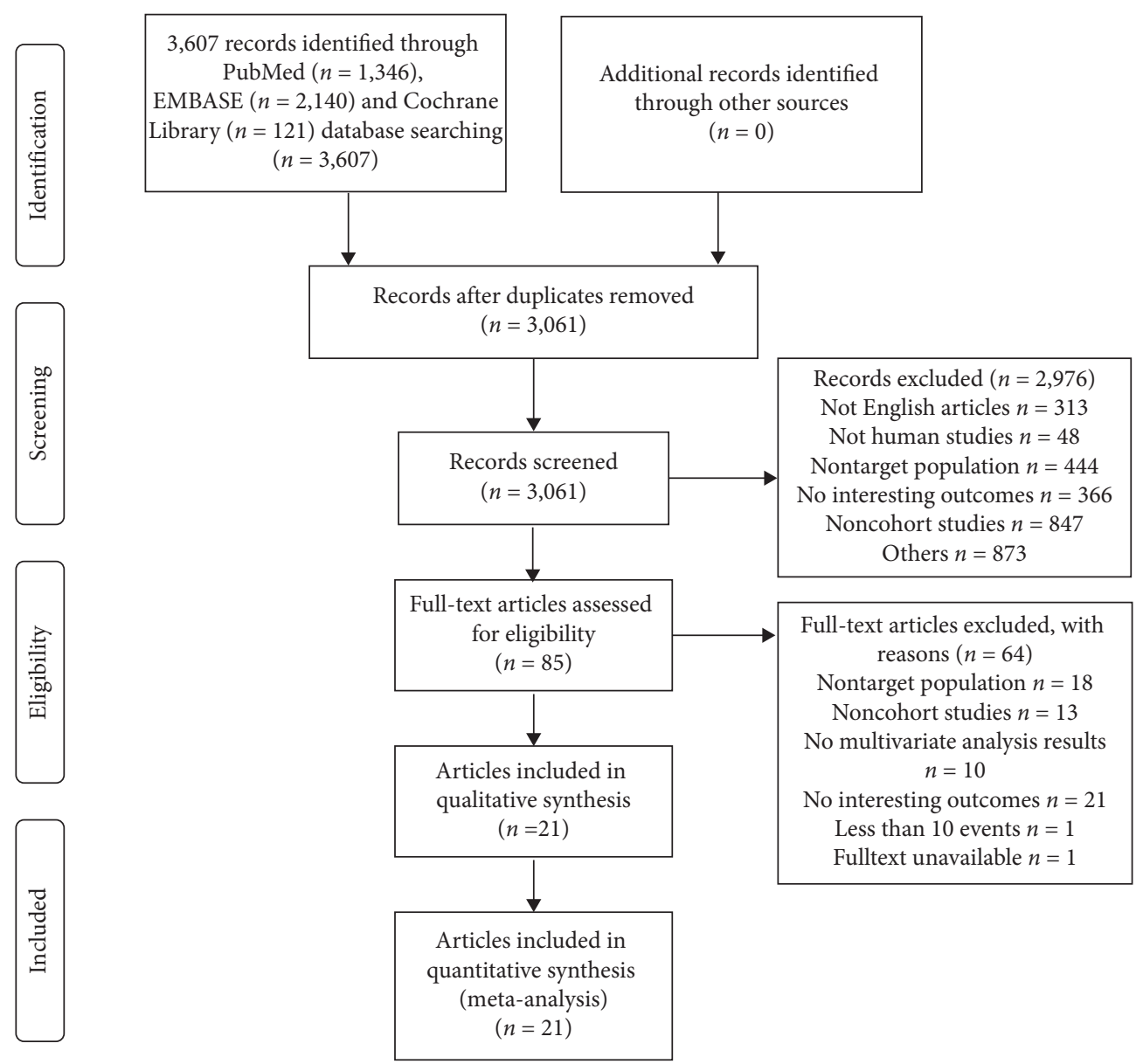

FIGURE 1: PRISMA 2009 flow diagram in literature screening; nontarget population refers to nonrespiratory tract infection patients or pediatric patients; no interesting outcomes refer to no adjusted analysis results for risk factors were reported in eligible studies.

$[35,36]$, and neither HAP nor VAP was a risk factor for the increased MDR bacterial infection (OR: $1.79 ; 95 \%$ CI: 0.64 to $5.02 ; I^{2}=29.1 \%$, three studies) $[15,29,31]$ in the randomeffects model.

3.8. Publication Bias. For studies included in the metaanalysis which assessed prior antibiotic treatment $[14-16,19,26,28,30,34,36-38,41]$ as a risk factor, the quantitative evaluation of publication bias by Begg's $(P=0.115)$ and Egger's $(P=0.125)$ tests indicated that the publication bias was not statistically significant, thus suggesting that there was no publication bias for the studies that reported prior antibiotic treatment as a risk factor.

We subdivided studies reporting prior antibiotic treatment into different groups, from which we obtained similar results to the overall results when the eligible studies were divided by kinds of organisms or definitions of MDR. Meanwhile, the subgroup analysis divided by diagnosis showed that prior antibiotic treatment was a risk factor for the acquisition of MDR bacteria in patients with HAP $[26,37,38]$, VAP $[34,41]$, pneumonia $[15,36]$, bronchiectasis [30], and AECOPD [42] except for CAP [14, 16, 28]. In the CAP subgroup $[14,16,28]$, the pooled analysis results suggested that prior antibiotic treatment was significantly associated with MDR bacterial infection after we ruled out the adjusted OR value of the study of Villafuerte et al. [16], which defined prior antibiotic treatment as antibiotics use during the last 12 months, far longer than the time frames reported in other studies. The results of the subgroup analysis are presented in Table 4 .

3.9. Sensitivity Analysis. Compared with the use of the random-effects model (DL method), when we performed data synthesis using the fixed-effects model, the pooled adjusted ORs for all risk factors did not change significantly. Nine risk factors obtained no significant result in the HKSJ method for meta-analysis, while results were statistically significant using the DL method. The results of sensitivity analysis using the fixed-effects model and HKSJ randomeffects model are presented in Tables S6 and S7.

\section{Discussion}

LRTIs are highly prevalent and variable and confer considerable morbidity and mortality [43]. The increasing rates of MDR bacteria are a worldwide public health problem. This review indicates that such risk factors as prior antibiotic treatment, inappropriate antibiotic therapy, chronic lung 
TABLE 1: The baseline characteristics of included studies.

\begin{tabular}{|c|c|c|c|c|c|c|c|c|c|c|c|}
\hline Study ID & Year & Study type & Countries & $\begin{array}{l}\text { No. of } \\
\text { centers }\end{array}$ & Setting & Population & $\begin{array}{c}\text { No. of } \\
\text { patients }\end{array}$ & $\begin{array}{l}\text { No. of } \\
\text { MDROs }\end{array}$ & $\begin{array}{c}\text { MDR } \\
\text { strains }\end{array}$ & $\begin{array}{c}\text { Age } \\
\text { (years) }^{\mathrm{a}}\end{array}$ & $\begin{array}{c}\text { Male } \\
(\%)\end{array}$ \\
\hline $\begin{array}{l}\text { Villafuerte } \\
\text { and } \\
\text { Aliberti } \\
{[16]}\end{array}$ & 2019 & Prospective & $\begin{array}{c}54 \\
\text { countries }\end{array}$ & 222 & $\begin{array}{c}\text { Internal and } \\
\text { emergency } \\
\text { medicine, } \\
\text { infectious } \\
\text { diseases, critical } \\
\text { care and } \\
\text { pulmonary } \\
\text { medicine }\end{array}$ & CAP & 3193 & 38 & EB & $\begin{array}{c}68.0(54.0 \\
80.0)\end{array}$ & 58.8 \\
\hline $\begin{array}{l}\text { Restrepo } \\
\text { et al. [17] }\end{array}$ & 2017 & Prospective & $\begin{array}{c}54 \\
\text { countries }\end{array}$ & 222 & $\begin{array}{c}\text { Internal and } \\
\text { emergency } \\
\text { medicine, } \\
\text { infectious } \\
\text { diseases, critical } \\
\text { care and } \\
\text { pulmonary } \\
\text { medicine }\end{array}$ & CAP & 133 & 33 & PA & $\begin{array}{l}64.4(52.5 \\
78.5)\end{array}$ & 59.4 \\
\hline \multirow{2}{*}{$\begin{array}{l}\text { Feng et al. } \\
{[26]}\end{array}$} & \multirow{2}{*}{2019} & \multirow{2}{*}{ Retrospective } & \multirow{2}{*}{ China } & \multirow{2}{*}{ Single } & $\begin{array}{l}\text { Pulmonary and } \\
\text { critical care }\end{array}$ & HAP & 313 & 193 & $\begin{array}{l}\mathrm{EB} \\
\mathrm{SA}\end{array}$ & NA & 72.5 \\
\hline & & & & & $\begin{array}{c}\text { medicine, } \\
\text { surgical ICU }\end{array}$ & VAP & 106 & 78 & $\begin{array}{l}\text { EB, } \\
\text { SA }\end{array}$ & NA & 67.0 \\
\hline $\begin{array}{l}\text { Zhou et al. } \\
\text { [27] }\end{array}$ & 2018 & Retrospective & China & Single & $\begin{array}{c}\text { Institute of } \\
\text { Respiratory } \\
\text { Diseases, } \\
\text { Division of } \\
\text { Respiratory } \\
\text { Diseases of } \\
\text { Department of } \\
\text { Internal } \\
\text { Medicine, } \\
\text { Department of } \\
\text { Pediatrics }\end{array}$ & HAP & 157 & 69 & PA & $57.8 \pm 17.8$ & 71.3 \\
\hline $\begin{array}{l}\text { Luan et al. } \\
\text { [28] }\end{array}$ & 2018 & Retrospective & China & Single & $\begin{array}{l}\text { Department of } \\
\text { Infectious } \\
\text { Diseases }\end{array}$ & CAP & 176 & 29 & $\begin{array}{l}\text { EB, } \\
\text { SA, SP }\end{array}$ & $68.3 \pm 4.3$ & 53.4 \\
\hline $\begin{array}{l}\text { Lewis et al. } \\
\text { [29] }\end{array}$ & 2018 & Retrospective & USA & Single & Trauma ICU & VAP & 397 & 135 & $\begin{array}{l}\mathrm{AB} \\
\mathrm{PA}\end{array}$ & $\begin{array}{l}45.0(16.0 \\
85.0)\end{array}$ & 78.0 \\
\hline $\begin{array}{l}\text { Gao et al. } \\
{[30]}\end{array}$ & 2018 & Retrospective & China & Single & $\begin{array}{l}\text { Department of } \\
\text { Respiratory and } \\
\text { Critical Care } \\
\text { Medicine, } \\
\text { Department of } \\
\text { Emergency } \\
\text { Medicine }\end{array}$ & Bronchiectasis & 88 & 34 & PA & $59.7 \pm 18.2$ & 52.3 \\
\hline $\begin{array}{l}\text { Song et al. } \\
\text { [31] }\end{array}$ & 2017 & Retrospective & Korea & 3 & NA & HDAP & 105 & 24 & $\begin{array}{l}\text { GPB } \\
\& \\
\text { GNB }\end{array}$ & $\begin{array}{c}71.0(61.0 \\
76.0)\end{array}$ & 64.8 \\
\hline $\begin{array}{l}\text { Fernandez- } \\
\text { Barat et al. } \\
{[32]}\end{array}$ & 2017 & Prospective & Spain & Single & $\begin{array}{l}\text { Medical and } \\
\text { surgical ICUs }\end{array}$ & ICUAP & 64 & 22 & PA & $66.0 \pm 15.0$ & 73.4 \\
\hline $\begin{array}{l}\text { Huang } \\
\text { et al. [33] }\end{array}$ & 2016 & Retrospective & China & Single & Medical ICU & Pneumonia & 263 & 154 & $\begin{array}{l}\text { GPB } \\
\& \\
\text { GNB }\end{array}$ & $72.9 \pm 14.1$ & 62.3 \\
\hline $\begin{array}{l}\text { Cillóniz } \\
\text { et al. [14] }\end{array}$ & 2016 & Prospective & Spain & Single & Hospital clinic & CAP & 77 & 22 & PA & $71.4 \pm 14.6$ & 84.4 \\
\hline $\begin{array}{l}\text { Tedja et al. } \\
\text { [34] }\end{array}$ & 2014 & Retrospective & USA & Single & $\begin{array}{l}\text { Medical, surgical, } \\
\text { cardiovascular, } \\
\text { coronary, and } \\
\text { neurologic ICU }\end{array}$ & VAP & 107 & 49 & $\begin{array}{l}\text { GPB } \\
\& \\
\text { GNB }\end{array}$ & $62.0 \pm 14.0$ & 55.0 \\
\hline
\end{tabular}


TABLE 1: Continued.

\begin{tabular}{|c|c|c|c|c|c|c|c|c|c|c|c|}
\hline Study ID & Year & Study type & Countries & $\begin{array}{l}\text { No. of } \\
\text { centers }\end{array}$ & Setting & Population & $\begin{array}{c}\text { No. of } \\
\text { patients }\end{array}$ & $\begin{array}{l}\text { No. of } \\
\text { MDROs }\end{array}$ & $\begin{array}{c}\text { MDR } \\
\text { strains }\end{array}$ & $\begin{array}{c}\text { Age } \\
\text { (years) }^{\mathrm{a}}\end{array}$ & $\begin{array}{c}\text { Male } \\
(\%)\end{array}$ \\
\hline $\begin{array}{l}\text { Özgür et al. } \\
\text { [35] }\end{array}$ & 2014 & Retrospective & Turkey & Single & $\begin{array}{l}\text { Medical, surgical, } \\
\text { adult ICU }\end{array}$ & VAP & 134 & 34 & $\mathrm{AB}$ & $53.2 \pm 21.0$ & 59.0 \\
\hline $\begin{array}{l}\text { Gross et al. } \\
{[15]}\end{array}$ & 2014 & Retrospective & USA & Single & $\begin{array}{c}\text { Academic } \\
\text { medical center }\end{array}$ & $\begin{array}{l}\text { CAP or } \\
\text { HCAP }\end{array}$ & 521 & 20 & $\begin{array}{c}\text { GPB } \\
\& \\
\text { GNB }\end{array}$ & $\begin{array}{l}65.0(52.0 \\
79.0)\end{array}$ & 44.5 \\
\hline $\begin{array}{l}\text { Wang et al. } \\
\text { [37] }\end{array}$ & 2013 & Prospective & China & Single & $\begin{array}{c}\text { Tertiary teaching } \\
\text { hospital }\end{array}$ & HAP & 102 & 24 & MRSA & $74.9 \pm 12.4$ & 64.7 \\
\hline $\begin{array}{l}\text { Zheng et al. } \\
{[36]}\end{array}$ & 2013 & Retrospective & China & Single & $\begin{array}{l}\text { Hospital } \\
\text { affiliated to a } \\
\text { university }\end{array}$ & Pneumonia & 242 & 97 & $\mathrm{AB}$ & $61.4 \pm 9.8$ & 54.9 \\
\hline $\begin{array}{l}\text { Seligman } \\
\text { et al. [38] }\end{array}$ & 2013 & Retrospective & Brazil & Single & $\begin{array}{c}\text { Tertiary care } \\
\text { teaching hospital }\end{array}$ & HAP & 140 & 59 & $\begin{array}{l}\text { GPB } \\
\& \\
\text { GNB }\end{array}$ & $63.0 \pm 14.4$ & 70.0 \\
\hline $\begin{array}{l}\text { Hamet } \\
\text { et al. [39] }\end{array}$ & 2012 & Prospective & France & Single & ICU & VAP & 323 & 90 & $\begin{array}{c}\text { GPB } \\
\& \\
\text { GNB }\end{array}$ & $63.4 \pm 15.2$ & 66.9 \\
\hline $\begin{array}{l}\text { Shi et al. } \\
{[40]}\end{array}$ & 2010 & Prospective & China & Single & $\begin{array}{l}\text { Hospital } \\
\text { affiliated to a } \\
\text { university }\end{array}$ & Pneumonia & 475 & 57 & GNB & $42.6 \pm 11.3$ & 89.7 \\
\hline $\begin{array}{l}\text { Depuydt } \\
\text { et al. [41] }\end{array}$ & 2008 & Prospective & Belgium & Single & $\begin{array}{l}\text { Medical and } \\
\text { surgical ICU }\end{array}$ & VAP & 192 & 52 & $\begin{array}{l}\text { GPB } \\
\& \\
\text { GNB }\end{array}$ & $59.4 \pm 16.1$ & 71.9 \\
\hline $\begin{array}{l}\text { Nseir and } \\
\text { Ader [42] }\end{array}$ & 2006 & Prospective & France & Single & ICU & AECOPD & 788 & 69 & $\begin{array}{l}\text { GPB } \\
\& \\
\text { GNB }\end{array}$ & $66.2 \pm 11.9$ & 76.8 \\
\hline
\end{tabular}

${ }^{\mathrm{a}}$ Mean \pm SD or median (IQR); MDR: multidrug resistance; MDROs: multidrug-resistant organisms; no.: number; ICU: intensive care unit; CAP: communityacquired pneumonia; HAP: hospital-acquired pneumonia; VAP: ventilator-associated pneumonia; HDAP: hemodialysis-associated pneumonia; ICUAP: intensive care unit-acquired pneumonia; HCAP: healthcare-associated pneumonia; AECOPD: acute exacerbation of chronic obstructive pulmonary disease; GNB: Gram-negative bacteria; GPB and GNB: Gram-negative bacteria and Gram-positive bacteria; EB: Enterobacteriaceae; PA: Pseudomonas aeruginosa; SA: Staphylococcus aureus; SP: Streptococcus pneumoniae; MRSA: methicillin-resistant Staphylococcus aureus; AB: Acinetobacter baumannii.

disease, chronic liver disease, cerebral disease, prior MDR infection/colonization, recent hospitalization, longer duration of hospitalization, previous or present endotracheal intubation or mechanical ventilation, tube feeding, and higher disease severity scores had a statistically significant association with the acquisition of MDR bacterial infection.

For antibiotic treatment, the present study found that prior antibiotic treatment was a significant risk factor for MDR bacterial infection in LRTIs. This finding is similar to that of the previous studies, which identified the risk factors for MDR PA infection in hospitalized patients [44] and MDR GNB infection in intensive care units [45]. The above two systematic reviews could not specify the definitions of previous antibiotic use, nor can they conclude an exact cutoff point for the time frame. Even if the eligible studies had inconsistent definitions of prior antibiotic treatment, we suggest defining it as the use of antibiotics within 90 days in clinical practice. The IDSA/ATS Guidelines 2016 [20] also suggested that the prior intravenous antibiotic use within 90 days was an important factor for HAP and VAP. Studies [46-48] have consistently reported that inappropriate antibiotic therapy, such as overuse or underuse of empirical antibiotics, could result in an increase in drug-resistant bacteria and generate new disease burdens [49]. The carbapenem-resistant Enterobacteriaceae (CRE), whose continuous emergence over the past decade has caused global attention, is significantly related to the increasing use of carbapenems [47, 50]. Two meta-analyses [51, 52] proved that exposure to carbapenems could increase the risk of CRKP by three to four times. Owing to the high mortality of patients with CRKP and fewer alternative treatment options, experts have proposed to limit the excess use of carbapenems [53].

The IDSA/ATS Guidelines 2016 [20] proposed that five or more days of hospitalization prior to the occurrence of VAP was considered a factor that increased the risk of MDR bacterial infection. This review confirms that recent hospitalization and prolonged hospital stays can increase the risk of MDR bacteria. A meta-analysis [51] suggested that prior hospitalization (within the previous 6 months) was a predictor for CRKP infection, and the present review indicated the appropriate cutoff value of the time frame for recent hospitalization was 90 days. Furthermore, we did agree that prolonged hospital stay could increase the risk of MDR bacterial infections [51].

Patients with comorbidities, such as chronic respiratory disease (COPD, asthma, and bronchiectasis), chronic liver disease, and cerebral disease are associated with the development of MDR bacteria, as they are particularly susceptible to bacterial infections and usually require repeated hospitalizations, antibiotic treatment, and invasive procedures $[42,54]$. The same is true for more severe patients who have 
TABLE 2: Risk of bias assessment of eligible studies based on QUIPS tool.

\begin{tabular}{|c|c|c|c|c|c|c|c|}
\hline Study ID & $\begin{array}{c}\text { Study } \\
\text { participation }\end{array}$ & $\begin{array}{c}\text { Study } \\
\text { attrition }\end{array}$ & $\begin{array}{c}\text { Prognostic factor } \\
\text { measurement }\end{array}$ & $\begin{array}{c}\text { Outcome } \\
\text { measurement }\end{array}$ & $\begin{array}{c}\text { Study } \\
\text { confounding }\end{array}$ & $\begin{array}{l}\text { Statistical analysis } \\
\text { and reporting }\end{array}$ & $\begin{array}{l}\text { Overall risk } \\
\text { of bias }\end{array}$ \\
\hline $\begin{array}{l}\text { Vilafuerte and } \\
\text { Aliberti [16] }\end{array}$ & Low & Low & Low & Low & Low & Low & Low \\
\hline $\begin{array}{l}\text { Restrepo et al. } \\
{[17]}\end{array}$ & Low & Low & Low & Low & Low & Low & Low \\
\hline Feng et al. [26] & Low & Low & Moderate & Low & Moderate & Low & Moderate \\
\hline Zhou et al. [27] & Low & Low & Low & Low & Low & Low & Low \\
\hline Luan et al. [28] & Low & Low & High & High & Low & Low & High \\
\hline Lewis et al. [29] & Low & Low & Low & Low & Low & Low & Low \\
\hline Gao et al. [30] & Low & Low & Low & Low & Low & Low & Low \\
\hline Song et al. [31] & Low & Low & Low & Low & Low & Low & Low \\
\hline $\begin{array}{l}\text { Fernandez-Barat } \\
\text { et al. [32] }\end{array}$ & Low & Low & High & High & Low & Low & High \\
\hline Huang et al. [33] & Low & Low & Low & Low & Low & Low & Low \\
\hline $\begin{array}{l}\text { Cillóniz et al. } \\
\text { [14] }\end{array}$ & Low & Low & Low & Moderate & Low & Low & Low \\
\hline Tedja et al. [34] & Low & Low & Moderate & Moderate & Moderate & Low & Moderate \\
\hline Özgüret al. [35] & Low & Low & Low & Low & Low & Low & Low \\
\hline Grosset al. [15] & Low & Low & Low & Low & Low & Low & Low \\
\hline Wang et al. [37] & Moderate & Low & Moderate & Low & Moderate & Low & Moderate \\
\hline Zheng et al. [36] & Moderate & Low & Low & Low & Low & Low & Low \\
\hline $\begin{array}{l}\text { Seligman et al. } \\
\text { [38] }\end{array}$ & Moderate & Low & Low & Low & Low & Low & Low \\
\hline Hamet et al. [39] & Low & Low & Low & Low & Low & Low & Low \\
\hline Shi et al. [40] & Moderate & Low & Low & Low & Moderate & Low & Moderate \\
\hline $\begin{array}{l}\text { Depuydt et al. } \\
\text { [41] }\end{array}$ & Low & Low & Low & Low & Low & Low & Low \\
\hline $\begin{array}{l}\text { Nseir and Ader } \\
{[42]}\end{array}$ & Low & Low & Low & Low & Low & Low & Low \\
\hline
\end{tabular}

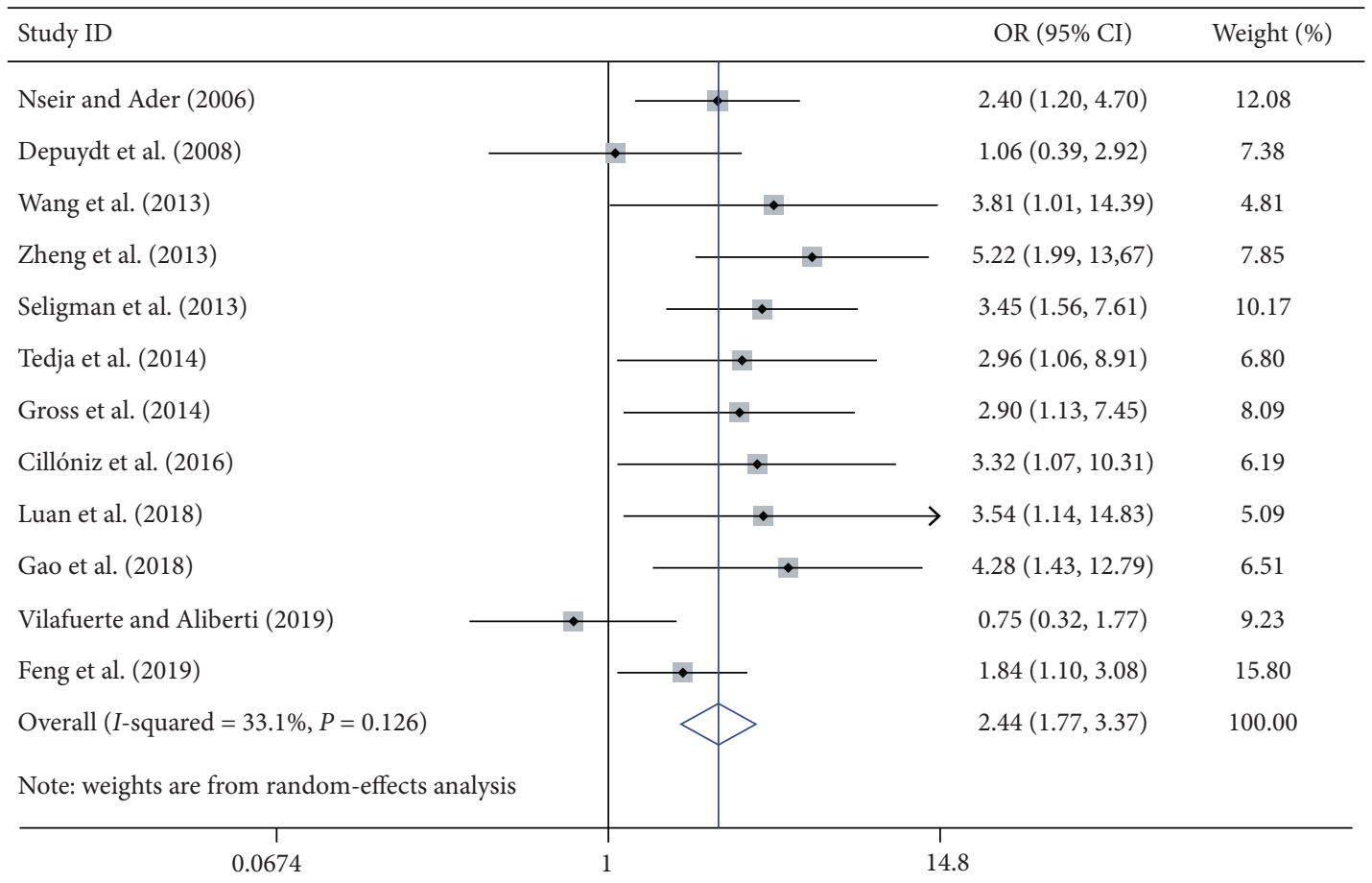

FIGURE 2: Forest plot of the meta-analysis regarding the MDR bacterial infection due to prior antibiotic treatment in the random-effects model. OR: odds ratio; CI: confidence interval. 
TABLE 3: Risk factors of MDR bacteria in terms of comorbidities

\begin{tabular}{lcccc}
\hline Risk factors & $\begin{array}{c}\text { No. of included } \\
\text { studies }\end{array}$ & $\begin{array}{c}\text { No. of included } \\
\text { MDROs }\end{array}$ & Heterogeneity & Synthesized results* \\
\hline $\begin{array}{l}\text { Chronic lung disease } \\
{[16,17,26,36,38]}\end{array}$ & 5 & 420 & $I^{2}=0.0 \%, P=0.611$ & OR: $2.19 ; 95 \%$ CI: 1.51 to \\
Chronic liver disease $[16,32]$ & 2 & 60 & $I^{2}=0.0 \%, P=0.403$ & OR: $3.41 ; 95 \%$ CI: 1.55 to \\
Cardiac disease $[16,38]$ & 2 & 97 & $I^{2}=57.9 \%$, & OR: $0.67 ; 95 \%$ CI: 0.25 to \\
Cerebral disease $[33,36,40]$ & 3 & 308 & $I^{2}=73.2 \%$, & OR: $2.98 ; 95 \%$ CI: 1.37 to \\
Renal replacement therapy $[15,38,41]$ & 3 & 131 & $I^{2}=0 \%, P=0.559$ & OR: $0.78 ; 95 \%$ CI: 0.41 to \\
\hline
\end{tabular}

MDROs: multidrug-resistant organisms. ${ }^{*}$ Using random-effects model.

TABLE 4: Subgroup analysis of studies reporting prior antibiotic treatment as a risk factor.

\begin{tabular}{|c|c|c|c|}
\hline Subgroups & No. of included studies & Heterogeneity & Synthesized results* \\
\hline $\begin{array}{l}\text { Divided by diagnosis } \\
\text { CAP }[14,16,28] \\
\text { HAP }[26,37,38] \\
\text { VAP }[34,41] \\
\text { Pneumonia }[15,36] \\
\text { Bronchiectasis }[30] \\
\text { AECOPD }[42]\end{array}$ & $\begin{array}{l}3 \\
3 \\
2 \\
2 \\
1 \\
1\end{array}$ & $\begin{array}{c}I^{2}=67.1 \%, P=0.048 \\
I^{2}=11.8 \%, P=0.322 \\
I^{2}=0.0 \%, P=0.169 \\
I^{2}=0.0 \%, P=0.170 \\
\text { NA } \\
\text { NA }\end{array}$ & $\begin{array}{l}\text { OR: } 1.92 ; 95 \% \text { CI: } 0.65 \text { to } 5.70 \\
\text { OR: } 2.40 ; 95 \% \text { CI: } 1.52 \text { to } 3.80 \\
\text { OR: } 2.63 \text {; } 95 \% \text { CI: } 1.24 \text { to } 5.55 \\
\text { OR: } 3.87 ; 95 \% \text { CI: } 1.97 \text { to } 7.59 \\
\text { OR: } 4.28 ; 95 \% \text { CI: } 1.43 \text { to } 12.80 \\
\text { OR: } 2.40 ; 95 \% \text { CI: } 1.21 \text { to } 4.75\end{array}$ \\
\hline $\begin{array}{l}\text { Divided by kinds of organisms } \\
\text { GNB [14, 16, 30, 36] } \\
\text { GNB and GPB [16, 26, 28, 34, 38, 41, 42] } \\
\text { GPB [37] }\end{array}$ & $\begin{array}{l}4 \\
7 \\
1\end{array}$ & $\begin{array}{c}I^{2}=72.7 \%, P=0.012 \\
I^{2}=0.0 \%, P=0.559 \\
\text { NA }\end{array}$ & $\begin{array}{l}\text { OR: } 2.65 ; 95 \% \text { CI: } 1.01 \text { to } 6.92 \\
\text { OR: } 2.44 ; 95 \% \text { CI: } 1.81 \text { to } 3.30 \\
\text { OR: } 3.81 ; 95 \% \text { CI: } 1.01 \text { to } 14.39\end{array}$ \\
\hline $\begin{array}{l}\text { Divided by definitions of MDR } \\
\text { Definition A }[14,16,26,30,34,36-38,41] \\
\text { Definition B }[15,42] \\
\text { No definition }[28]\end{array}$ & $\begin{array}{l}9 \\
2 \\
1\end{array}$ & $\begin{array}{c}I^{2}=40.4 \%, P=0.098 \\
I^{2}=0.0 \%, P=0.750 \\
\text { NA }\end{array}$ & $\begin{array}{l}\text { OR: } 2.57 ; 95 \% \text { CI: } 1.72 \text { to } 3.82 \\
\text { OR: } 2.56 ; 95 \% \text { CI: } 1.47 \text { to } 4.45 \\
\text { OR: } 3.54 ; 95 \% \text { CI: } 0.98 \text { to } 12.77\end{array}$ \\
\hline
\end{tabular}

higher disease severity scores. Besides, studies have shown that the colonization of GNB, especially PA, was common in patients with chronic respiratory disease. It is prone to recurrent infection [55-57], followed by frequent antibiotic exposure, which positively selects for MDR bacteria. The IDSA/ATS Guidelines 2016 [20] and Zhu et al. [51] pointed out that the patients with renal dysfunction or dialysis were at increased risk of infection with MDR bacteria, which had not been confirmed in this study.

Consistent with previous meta-analysis [51, 52], we found that intubation/ventilation (within the previous 6 months) and prior MDR bacterial infection/colonization (within the previous 6 months) were significantly associated with the increase of MDR bacteria.

The sensitivity analysis suggested that the results of the HKSJ method did not fully agree with those of the DL method. Nine significant risk factors including inappropriate antibiotic therapy, chronic liver disease, cerebral disease, prior MDR infection, prior PA infection, endotracheal intubation, mechanical ventilation, tube feeding, and disease severity scores did not obtain significant results when using the HKSJ method, although the studies included in the meta-analysis were statistically significant with effects pointing into the same direction. This might be because the risk factors only reported by very few (i.e., 2 or 3) studies, and the HKSJ method had very low power and leads to a statistically not significant pooled effect estimate [58, 59]. The meta-analysis results of the above nine risk factors should be regarded with caution.

To the best of our knowledge, this review is the first one that conducts a meta-analysis by focusing on risk factors for MDR bacteria in LRTIs, but there are also some limitations. Firstly, due to the limited number of included studies, subgroup analyses based on diagnosis, kinds of organisms, or definitions of MDR bacteria were not conducted for most risk factors. Thus, it might limit the generalizability of the 
results. Secondly, the different definitions of MDR bacteria used in the original literature may introduce deviations in the results, even though most studies had the same definition that the MDR bacteria were not sensitive to at least one agent in three or more antimicrobial categories. Thirdly, some factors including previous antibiotic treatment, recent hospitalization, and previous tracheostomy were not defined consistently across studies and even were not defined clearly in some studies, leading to the reduction in the precision of the results. Fourthly, limited evidence exists to inform which method performs best for a random-effects meta-analysis, especially when studies are few in number $(<5)$. Therefore, we applied the commonly used random-effects model (DL method) for our primary analysis. The DL method might generate too many statistically significant results when the number of studies is small and there is moderate or substantial heterogeneity [60]. To ensure the robustness of the meta-analysis results, HKSJ random-effects model was used for sensitivity analysis.

\section{Conclusions}

This meta-analysis indicates that prior antibiotic treatment in the past 90 days, inappropriate antibiotic therapy, chronic lung disease, chronic liver disease, cerebral disease, prior MDR infection/colonization in the past 12 months, hospitalization in the past 90 days, longer hospitalization stay, previous endotracheal intubation or mechanical ventilation in the past 6 months, tube feeding, and higher the disease severity scores were risk factors for the acquisition of MDR bacteria. Clinicians could take into account these factors when selecting antibiotics for patients and determine whether coverage for MDR is required in clinical practice. More well-designed studies are needed to confirm the various risk factors for MDR bacteria in the future.

\section{Disclosure}

Gang Chen and Kailiang $\mathrm{Xu}$ should be considered co-first authors.

\section{Conflicts of Interest}

The authors declare that they have no conflicts of interest.

\section{Authors' Contributions}

Gang Chen and Kailiang Xu contributed equally to this work.

\section{Supplementary Materials}

Table S1: search strategies in PubMed. Table S2: search strategies in EMBASE. Table S3: search strategies in Cochrane Library. Table S4: studies excluded in the full-text screening process. Table S5: additional risk factors that had a statistically significant association with the acquisition of MDR bacteria. Table S6: results of sensitivity analysis using the fixed-effects models. Table S7: results of sensitivity analysis using the HKSJ random-effects model. (Supplementary Materials)

\section{References}

[1] G. A. Roth, D. Abate, K. H. Abate et al., "Global, regional, and national age-sex-specific mortality for 282 causes of death in 195 countries and territories, 1980-2017: a systematic analysis for the global burden of disease study 2017," Lancet, vol. 392, no. 10159, pp. 1736-1788, 2018.

[2] C. Troeger, B. Blacker, I. A. Khalil et al., "Estimates of the global, regional, and national morbidity, mortality, and aetiologies of lower respiratory infections in 195 countries, 1990-2016: a systematic analysis for the global burden of disease study 2016," The Lancet Infectious Diseases, vol. 18, no. 11, pp. 1191-1210, 2018.

[3] J. Ho and M. Ip, "Antibiotic-resistant community-acquired bacterial pneumonia," Infectious Disease Clinics of North America, vol. 33, no. 4, pp. 1087-1103, 2019.

[4] D. Gu, N. Dong, Z. Zheng et al., "A fatal outbreak of ST11 carbapenem-resistant hypervirulent Klebsiella pneumoniae in a Chinese hospital: a molecular epidemiological study," The Lancet Infectious Diseases, vol. 18, no. 1, pp. 37-46, 2018.

[5] W. P. Tseng, Y. C. Chen, S. Y. Chen, S. Y. Chen, and S. C. Chang, "Risk for subsequent infection and mortality after hospitalization among patients with multidrug-resistant gram-negative bacteria colonization or infection," Antimicrobial Resistance and Infection Control, vol. 7, no. 1, p. 93, 2018.

[6] S. Siwakoti, A. Subedi, A. Sharma, R. Baral, N. R. Bhattarai, and B. Khanal, "Incidence and outcomes of multidrug-resistant gram-negative bacteria infections in intensive care unit from Nepal-a prospective cohort study," Antimicrobial Resistance and Infection Control, vol. 7, no. 1, p. 114, 2018.

[7] R. E. Nelson, R. B. Slayton, V. W. Stevens et al., "Attributable mortality of healthcare-associated infections due to multidrug-resistant gram-negative bacteria and methicillin-resistant Staphylococcus aureus," Infection Control \& Hospital Epidemiology, vol. 38, no. 7, pp. 848-856, 2017.

[8] A. Zumla, Z. A. Memish, M. Maeurer et al., "Emerging novel and antimicrobial-resistant respiratory tract infections: new drug development and therapeutic options," The Lancet Infectious Diseases, vol. 14, no. 11, pp. 1136-1149, 2014.

[9] B. Gao, X. Li, F. Yang et al., "Molecular epidemiology and risk factors of ventilator-associated pneumonia infection caused by carbapenem-resistant enterobacteriaceae," Frontiers in Pharmacology, vol. 10, p. 262, 2019.

[10] T. D. Trinh, E. J. Zasowski, K. C. Claeys et al., "Multidrugresistant Pseudomonas aeruginosa lower respiratory tract infections in the intensive care unit: prevalence and risk factors," Diagnostic Microbiology and Infectious Disease, vol. 89, no. 1, pp. 61-66, 2017.

[11] S. Piano, V. Singh, and P. Caraceni, "Epidemiology and effects of bacterial infections in patients with cirrhosis worldwide," Gastroenterology, vol. 156, no. 5, pp. 1368-1380, 2019.

[12] J. Wang, B. Foxman, L. Mody, and E. S. Snitkin, "Network of microbial and antibiotic interactions drive colonization and infection with multidrug-resistant organisms," Proceedings of the National Academy of Sciences, vol. 114, no. 39, pp. 10467-10472, 2017.

[13] T. Snitkin, O. Ribeiro, I. C. Aragão, A. Costa-Pereira, and A. E. Sarmento, "Additional risk factors for infection by multidrug-resistant pathogens in healthcare-associated 
infection: a large cohort study," BMC Infectious Diseases, vol. 12, no. 1, p. 375, 2012.

[14] C. Cillóniz, A. Gabarrús, M. Ferrer et al., "Community-acquired pneumonia due to multidrug- and non-multidrugresistant Pseudomonas aeruginosa," Chest, vol. 150, no. 2, pp. 415-425, 2016.

[15] A. E. Gross, T. C. Van Schooneveld, K. M. Olsen et al., "Epidemiology and predictors of multidrug-resistant community-acquired and health care-associated pneumonia," Antimicrobial Agents and Chemotherapy, vol. 58, no. 9, pp. 5262-5268, 2014.

[16] D. Villafuerte, S. Aliberti, N. J. Soni et al., "Prevalence and risk factors for Enterobacteriaceae in patients hospitalized with community-acquired pneumonia," Respirology, vol. 25, no. 5, pp. 543-551, 2019.

[17] M. I. Restrepo, B. L. Babu, L. F. Reyes et al., "Burden and risk factors for Pseudomonas aeruginosa community-acquired pneumonia: a multinational point prevalence study of hospitalised patients," European Respiratory Journal, vol. 52, no. 2, Article ID 1701190, 2018.

[18] Y. J. Li, C. Z. Pan, C. Q. Fang et al., "Pneumonia caused by extensive drug-resistant Acinetobacter baumannii among hospitalized patients: genetic relationships, risk factors and mortality," BMC Infectious Diseases, vol. 17, no. 1, p. 371, 2017.

[19] S. Nseir, C. D. Pompeo, B. Cavestri et al., "Multiple-drugresistant bacteria in patients with severe acute exacerbation of chronic obstructive pulmonary disease: prevalence, risk factors, and outcome," Critical Care Medicine, vol. 34, no. 12, pp. 2959-2966, 2006.

[20] A. C. Kalil, M. L. Metersky, M. Klompas et al., "Management of adults with hospital-acquired and ventilator-associated pneumonia: 2016 clinical practice guidelines by the infectious diseases society of America and the American thoracic society," Clinical Infectious Diseases, vol. 63, no. 5, pp. e61-e111, 2016.

[21] A. Liberati, D. G. Altman, J. Tetzlaff et al., "The PRISMA statement for reporting systematic reviews and meta-analyses of studies that evaluate healthcare interventions: explanation and elaboration," British Medical Journal, vol. 339, p. b2700, 2009.

[22] A.-P. Magiorakos, A. Srinivasan, R. B. Carey et al., "Multidrug-resistant, extensively drug-resistant and pandrug-resistant bacteria: an international expert proposal for interim standard definitions for acquired resistance," Clinical Microbiology and Infection, vol. 18, no. 3, pp. 268-281, 2012.

[23] American Thoracic Society and Infectious Diseases Society of America, "Guidelines for the management of adults with hospital-acquired, ventilator-associated, and healthcare-associated pneumonia," American Journal of Respiratory and Critical Care Medicine, vol. 171, no. 4, pp. 388-416, 2005.

[24] J. A. Hayden, P. Côté, and C. Bombardier, "Evaluation of the quality of prognosis studies in systematic reviews," Annals of Internal Medicine, vol. 144, no. 6, pp. 427-437, 2006.

[25] F. Foroutan, G. H. Guyatt, K. O’Brien et al., "Prognosis after surgical replacement with a bioprosthetic aortic valve in patients with severe symptomatic aortic stenosis: systematic review of observational studies," British Medical Journal, vol. 354, p. i5065, 2016.

[26] D.-Y. Feng, Y.-Q. Zhou, X.-L. Zou et al., "Differences in microbial etiology between hospital-acquired pneumonia and ventilator-associated pneumonia: a single-center retrospective study in Guang Zhou," Infection and Drug Resistance, vol. 12, pp. 993-1000, 2019.
[27] Y.-Q. Zhou, D.-Y. Feng, W.-J. Li et al., "Lower neutrophil-tolymphocyte ratio predicts high risk of multidrug-resistant pseudomonas aeruginosa infection in patients with hospitalacquired pneumonia," Therapeutics and Clinical Risk Management, vol. 14, pp. 1863-1869, 2018.

[28] Y. Luan, Y. Sun, S. Duan, P. Zhao, and Z. Bao, "Pathogenic bacterial profile and drug resistance analysis of communityacquired pneumonia in older outpatients with fever," Journal of International Medical Research, vol. 46, no. 11, pp. 45964604, 2018.

[29] R. H. Lewis, J. P. Sharpe, J. M. Swanson, T. C. Fabian, M. A. Croce, and L. J. Magnotti, "Reinventing the wheel," Journal of Trauma and Acute Care Surgery, vol. 85, no. 2, pp. 256-262, 2018.

[30] Y.-H. Gao, W.-J. Guan, Y.-N. Zhu, R.-C. Chen, and G.-J. Chen, “Antibiotic-resistant Pseudomonas aeruginosa infection in patients with bronchiectasis: prevalence, risk factors and prognostic implications," International Journal of Chronic Obstructive Pulmonary Disease, vol. 13, pp. 237-246, 2018.

[31] J. U. Song, H. K. Park, H. K. Kang, and J. Lee, "Proposed risk factors for infection with multidrug-resistant pathogens in hemodialysis patients hospitalized with pneumonia," BMC Infectious Diseases, vol. 17, no. 1, p. 681, 2017.

[32] L. Fernández-Barat, M. Ferrer, F. De Rosa et al., "Intensive care unit-acquired pneumonia due to Pseudomonas aeruginosa with and without multidrug resistance," Journal of Infection, vol. 74, no. 2, pp. 142-152, 2017.

[33] S.-F. Huang, J.-S. Chang, C.-C. Sheu, Y.-T. Liu, and Y.-C. Liu, "An antibiotic decision-making tool for patients with pneumonia admitted to a medical intensive care unit," International Journal of Antimicrobial Agents, vol. 48, no. 3, pp. 286-291, 2016.

[34] R. Tedja, A. Nowacki, T. Fraser et al., "The impact of multidrug resistance on outcomes in ventilator-associated pneumonia," American Journal of Infection Control, vol. 42, no. 5, pp. 542-545, 2014.

[35] E. S. Özgür, E. S. Horasan, K. Karaca, G. Ersöz, S. N. Atış, and A. Kaya, "Ventilator-associated pneumonia due to extensive drug-resistant Acinetobacter baumannii: risk factors, clinical features, and outcomes," American Journal of Infection Control, vol. 42, no. 2, pp. 206-208, 2014.

[36] Y.-L. Zheng, Y.-F. Wan, L.-Y. Zhou et al., "Risk factors and mortality of patients with nosocomial carbapenem-resistant Acinetobacter baumannii pneumonia," American Journal of Infection Control, vol. 41, no. 7, pp. e59-e63, 2013.

[37] Y. Wang, Y. J. Hu, X. M. Ai, H.-T. Xu, and T.-Y. Sun, "Prevalence and clinical prognosis of heteroresistant vancomycin-intermediate Staphylococcus aureus in a tertiary care center in China," Chinese Medical Journal, vol. 126, no. 3, pp. 505-509, 2013.

[38] R. Seligman, L. F. Ramos-Lima, V. D. A. Oliveira, C. Sanvicente, J. Sartori, and E. F. Pacheco, "factors for infection with multidrug-resistant bacteria in non-ventilated patients with hospital-acquired pneumonia," Jornal Brasileiro de Pneumologia, vol. 39, no. 3, pp. 339-348, 2013.

[39] M. Hamet, A. Pavon, F. Dalle et al., "Candida spp. airway colonization could promote antibiotic-resistant bacteria selection in patients with suspected ventilator-associated pneumonia," Intensive Care Medicine, vol. 38, no. 8, pp. 1272-1279, 2012.

[40] S. H. Shi, H. S. Kong, C. K. Jia et al., "Risk factors for pneumonia caused by multidrug-resistant gram-negative 
bacilli among liver recipients," Clinical Transplantation, vol. 24, no. 6, pp. 758-765, 2010.

[41] P. O. Depuydt, D. M. Vandijck, M. A. Bekaert et al., "Determinants and impact of multidrug antibiotic resistance in pathogens causing ventilator-associated-pneumonia," Critical Care, vol. 12, no. 6, p. R142, 2008.

[42] S. Nseir and F. Ader, "Prevalence and outcome of severe chronic obstructive pulmonary disease exacerbations caused by multidrug-resistant bacteria," Current Opinion in Pulmonary Medicine, vol. 14, no. 2, pp. 95-100, 2008.

[43] M. Ruopp, K. Chiswell, J. T. Thaden, K. Merchant, and E. L. Tsalik, "Respiratory tract infection clinical trials from 2007 to 2012. A systematic review of clinicaltrials.gov," Annals of the American Thoracic Society, vol. 12, no. 12, pp. 1852$1863,2015$.

[44] G. Raman, E. E. Avendano, J. Chan, S. Merchant, and L. Puzniak, "Risk factors for hospitalized patients with resistant or multidrug-resistant Pseudomonas aeruginosa infections: a systematic review and meta-analysis," Antimicrobial Resistance and Infection Control, vol. 7, no. 1, p. 79, 2018.

[45] H. Ang and X. Sun, "Risk factors for multidrug-resistant gram-negative bacteria infection in intensive care units: a meta-analysis," International Journal of Nursing Practice, vol. 24, no. 4, p. 12644, 2018.

[46] J.-M. López-Lozano, T. Lawes, C. Nebot et al., “A nonlinear time-series analysis approach to identify thresholds in associations between population antibiotic use and rates of resistance," Nature Microbiology, vol. 4, no. 7, pp. 1160-1172, 2019.

[47] H. Wushouer, Z.-X. Zhang, J.-H. Wang et al., "Trends and relationship between antimicrobial resistance and antibiotic use in Xinjiang Uyghur autonomous Region, China: based on a 3 year surveillance data, 2014-2016," Journal of Infection and Public Health, vol. 11, no. 3, pp. 339-346, 2018.

[48] P.-R. Hsueh, W.-H. Chen, and K.-T. Luh, "Relationships between antimicrobial use and antimicrobial resistance in gram-negative bacteria causing nosocomial infections from 1991-2003 at a university hospital in Taiwan," International Journal of Antimicrobial Agents, vol. 26, no. 6, pp. 463-472, 2005.

[49] O. Jonas and W. Team, Drug-Resistant Infections: A Threat to Our Economic Future, World Bank, Washington, DC, USA, 2017.

[50] S. Mladenovic-Antic, B. Kocic, R. Velickovic-Radovanovic et al., "Correlation between antimicrobial consumption and antimicrobial resistance of Pseudomonas aeruginosain a hospital setting: a 10-year study," Journal of Clinical Pharmacy and Therapeutics, vol. 41, no. 5, pp. 532-537, 2016.

[51] W. M. Zhu, Z. Yuan, and H. Y. Zhou, "Risk factors for carbapenem-resistant Klebsiella pneumoniae infection relative to two types of control patients: a systematic review and metaanalysis," Antimicrobial Resistance \& Infection Control, vol. 9, no. 1, p. 23, 2020.

[52] P. Liu, X. Li, M. Luo et al., "Risk factors for carbapenemresistant Klebsiella pneumoniaeInfection: a meta-analysis," Microbial Drug Resistance, vol. 24, no. 2, pp. 190-198, 2018.

[53] M. Bassetti, M. Peghin, and D. Pecori, "The management of multidrug-resistant Enterobacteriaceae," Current Opinion in Infectious Diseases, vol. 29, no. 6, pp. 583-594, 2016.

[54] V. C. Patel and R. Williams, "Antimicrobial resistance in chronic liver disease," Hepatology International, vol. 14, no. 1, pp. 24-34, 2020.
[55] A. D. Valderrey, M. J. Pozuelo, P. A. Jiménez, M. D. Maciá, A. Oliver, and R. Rotger, "Chronic colonization by Pseudomonas aeruginosa of patients with obstructive lung diseases: cystic fibrosis, bronchiectasis, and chronic obstructive pulmonary disease," Diagnostic Microbiology and Infectious Disease, vol. 68, no. 1, pp. 20-27, 2010.

[56] T. F. Murphy, A. L. Brauer, K. Eschberger et al., "Pseudomonas aeruginosain chronic obstructive pulmonary disease," American Journal of Respiratory and Critical Care Medicine, vol. 177, no. 8, pp. 853-860, 2008.

[57] L. Martínez-Solano, M. D. Macia, A. Fajardo, A. Oliver, and J. L. Martinez, "Chronic Pseudomonas aeruginosa infection in chronic obstructive pulmonary disease," Clinical Infectious Diseases, vol. 47, no. 12, pp. 1526-1533, 2008.

[58] A. Gonnermann, T. Framke, A. Großhennig, and A. Koch, "No solution yet for combining two independent studies in the presence of heterogeneity," Statistics in Medicine, vol. 34, no. 16, pp. 2476-2480, 2015.

[59] T. Friede, C. Röver, S. Wandel, and B. Neuenschwander, "Meta-analysis of two studies in the presence of heterogeneity with applications in rare diseases," Biometrical Journal, vol. 59, no. 4, pp. 658-671, 2017.

[60] J. Neuenschwander, J. P. A. Ioannidis, and G. F. Borm, “The Hartung-Knapp-Sidik-Jonkman method for random effects meta-analysis is straightforward and considerably outperforms the standard DerSimonian-Laird method," BMC Medical Research Methodology, vol. 14, no. 25, 2014. 